Науковий вісник НЛтУ України
Scientific Bulletin of UNFU
http://nv.nltu.edu.ua
https://doi.org/10.15421/40280502
Article received 11.05.2018 p.
Article accepted 31.05.2018 p.
Удк 630*17.237:582.475.4(477.42)

С. Б. Ковалевський, А. В. Кроль

Національний університет біоресурсів і природокористування України, м. Київ, Україна

\title{
ОСОБЛИВОСТІ РОСТУ 30-50-РІЧНИХ КУЛЬТУР СОСНИ ЗВИЧАЙНОЇ ЖИТОМИРСЬКОГО ПОЛІССЯ НА ЗЕМЛЯХ ІЗ КАМ'ЯНИСТИМИ ПОРОДАМИ
}

\begin{abstract}
Виявлено закономірності росту та розвитку деревних рослин у насадженнях жердинного віку та середньовікових культурах сосни звичайної Житомирського Полісся. Дослідження проведено на ділянках із різною глибиною залягання кам'янистих порід у грунті. Встановлено, що на продуктивність насаджень у цьому віковому періоді впливають не тільки грунтові умови, а проведення доглядових рубань різної інтенсивності, що позначається на задернінні грунту, конкуренції за вологу та елементи мінерального живлення між деревними і трав'яними видами. Оцінено вплив наявності в грунті кам'янистих порід, зокрема їх залягання на різній глибині та кількості, на формування, розвиток та розростання кореневих систем, що надалі визначає ріст і стійкість насаджень загалом. Встановлено, що інтенсивність росту за висотою до 30-31 років дерев сосни звичайної в культурах на землях без кам'янистих порід дещо вища (в цей період різниця становить понад один метр), ніж у культурах із наявністю останніх у грунті. Після цього віку інтенсивність росту дерев сосни на обох ділянках однакова, але висота дерев сосни дещо більша в культурах без каміння в грунті. Середній діаметр дерев сосни вищий у культурах без каміння в грунті впродовж спостережень. Проте, незважаючи на досить високий запас стовбурової деревини в культурах, які створені на землях із наявністю каміння, товарна структура дерев сосни в них низька.
\end{abstract}

Ключові слова: соснові культури; кристалічні породи; грунт.

Вступ. Ліс - складне рослинне угруповання, яке змінюється у просторі та часі впродовж усього періоду свого існування. Для кожного з етапів лісу притаманні свої особливості росту, розвитку, взаємодії та взаємовпливу всіх його компонентів. Насадження у жердинному віці характеризується інтенсивним поглинанням поживних речовин і вологи з грунту, утворенням великої кількості підстилки до кінця 30-річного віку, відсутністю або слабким розвитком трав'яних рослин, сильною диференціацією дерев за розмірами. 3 кінця третього десятиріччя в насадженнях жердинного віку починає зріджуватись крона дерев. У цьому віковому періоді зімкнутих насаджень спостерігають інтенсивний ріст деревних видів за висотою. Повнота, яку визначають за сумами поперечного перетину стовбурів, значно нижча від загальної суми проекції крон дерев. Прочищенням насаджень жердинного віку прагнуть забезпечити склад, форму, чистоту і достатню кількість цінних для господарства дерев головних порід на одиниці площі. Сильні інтенсивні доглядові рубання супроводжуються уповільненням росту за висотою і сприяють появі трав'яних рослин (Gordienko, Ribak \& Gordienko, 1996).

У середньовікових культурах продовжується формування стовбурів і крони всіх деревних видів, але посилюється зрідження останніх, освітлення і прогрівання грунту, що сприяє поселенню трав'яних і деревних рослин (Pogrebniak, 1968). Значного впливу на інтенсивність росту і розвитку деревних видів завдає коренева система дерева, формування якої відбувається залежно від виду рослин і грунтових умов. Природно, слабо розвинена коренева система менше впливає на розвиток наземної частини дерев.

Матеріал і методи дослідження. Для проведення досліджень із вивчення особливостей росту сосни звичайної підбирали приблизно одновікові культури, які зростали в однакових умовах на грунтах із різною глибиною залягання кам'янистих порід. Пробні площі підбирали і закладали відповідно до загальноприйнятих методик (Gordienko, Mayrer \& Kovalevskiy, 2000). Усі дослідження проводили в умовах свіжих суборів у лісових культурах ДП "Коростишівське ЛГ" (табл. 1). Для більшої достовірності отриманих результатів дослідження проводили на пробних площах у різних лісництвах. У процесі дослідження вивчали таксаційні показники лісових культур, кількість дерев на гектарі, розміри крони та віддаль до першої гілки.

Результати дослідження. За даними М. І. Гордієнка та Г. В. Дубініна (Gordienko, Ribak \& Gordienko, 1996), в насадженнях сосни звичайної віком 19 років повнота, яку визначають за площами перетину стовбурів, становить 0,93, а зімкнутість крон, яку визначають за площею проекції крон, - 1154. У насадженнях сосни віком 33 роки це співвідношення знаходиться в межах 0,71 i 0,99, а вже в насадженнях віком 50 років ці величини зближаються, повнота становить 0,69 , а зімкнутість крон - 0,72. Отже, в насадженнях сосни до кінця жер-

\section{Інформація про авторів:}

Ковалевський Сергій Борисович, д-р с.-г. наук, професор, кафедра дендрологіï та лісової ceлекції. Email: s.kovalevsky@ukr.net Кроль Анатолій Віталійович, здобувач, кафедра дендрології та лісової селекції. Email: Kroltolya@ukr.net

Цитування за ДСту: Ковалевський С. Б., Кроль А. В. Особливості росту 30-50-річних культур сосни звичайної Житомирського Полісся на землях із кам'янистими породами. Науковий вісник НлтУ України. 2018, т. 28, № 5. С. 15-18.

Citation APA: Kovalevskii, S. B., \& Krol, A. V. (2018). Some peculiarities of growth of 30-50-year-old cultures of siver pine on stony soils in Zhytomyr polissya. Scientific Bulletin of UNFU, 28(5), 15-18. https://doi.org/10.15421/40280502 
динного віку повнота значно менша за величину, ніж зімкнутість крон. Пояснюють це тим, що гілки одних дерев заходять у сферу крони сусідніх. Це відбувається i в насадженнях сосни, які сформувались на грунтах із близьким заляганням кам'янистих порід і без них. Підтвердженням тому в усіх насадженнях близький за величиною діаметр крон $(1,8-2,5)$. Форма крони і приріст гілок за довжиною дерев сосни звичайної, як зазначає В. В. Миронов (Mironov, 1977), залежать від освітлення. Інтенсивний ріст дерев сосни звичайної, як наголошує В. В Миронов, спостерігають за умов раннього зімкнення гілок і освітлення зверху, а затінення - з боків крони.

Як і варто очікувати, у насадженнях сосни звичайної, які створені на землях із близьким і глибоким заляганням кам'яних порід, існує деяка різниця. Потрібно наголосити, що до земель із близьким заляганням кам'янис- тих порід відносимо ділянки 3 виходом цих порід на денну поверхню. Пояснюємо це тим, що основна маса (90,7-96,3 \%) фізіологічно активних корінців сосни звичайної у 9-10-річних культурах, які створені на свіжих дерново-підзолистих супіщаних грунтах Полісся (свіжі субори), розташована у верхньому 60-сантиметровому шарі, а в 20-23-річних культурах сосни теж Полісся $83,0-95,3 \%$ фізіологічних корінців сосни розташовані до глибини 60 см (Gordienko \& Gordienko, 2005).

У культурах жердинного віку, які сформувались на грунтах із близьким заляганням кам'янистих порід до денної поверхні й без останніх у грунті, сосна звичайна проявляє ріст за I-I ${ }^{\mathrm{a}}$ бонітетами. Проте в 37-річному насадженні Смолівського лісництва дерева сосни мають найменші розміри (середні висота 15,8 м і діаметр 14 см) (див. табл. 1).

Табл. 1. Характеристика культур сосни звичайної

\begin{tabular}{|c|c|c|c|c|c|c|c|c|c|c|}
\hline \multirow{2}{*}{$\begin{array}{l}\text { Квартал/ } \\
\text { виділ }\end{array}$} & \multirow{2}{*}{$\begin{array}{l}\text { Вік, } \\
\text { років }\end{array}$} & \multicolumn{2}{|c|}{ Середні } & \multirow[b]{2}{*}{ Повнота } & \multirow[b]{2}{*}{ Бонітет } & \multicolumn{3}{|c|}{ На гектарі } & \multicolumn{2}{|c|}{ Приріст дерев за } \\
\hline & & висота, м & діаметр, см & & & дерев, шт. & запас, м $^{3}$ & $\begin{array}{c}\text { середній } \\
\text { приріст, м }{ }^{3}\end{array}$ & висотою, м & $\begin{array}{l}\text { діаметром, } \\
\text { см }\end{array}$ \\
\hline \multicolumn{11}{|c|}{$\begin{array}{c}\text { На землях із близьким заляганням кам'янистих порід до денної поверхні } \\
\text { Дубовицьке лісництво }\end{array}$} \\
\hline $31 / 5$ & 37 & 17,0 & 20,1 & 0,96 & $\mathrm{I}^{\mathrm{a}}$ & 1165 & 290 & 7,8 & 0,46 & 0,54 \\
\hline $16 / 17$ & 56 & 24,1 & 21,9 & 0,79 & $\mathrm{I}^{\mathrm{a}}$ & 955 & 385 & 6,9 & 0,43 & 0,39 \\
\hline \multicolumn{11}{|c|}{ Коростишівське лісництво } \\
\hline $18 / 25$ & 37 & 15,8 & 22,0 & 0,71 & \begin{tabular}{|c|}
1 \\
\end{tabular} & 476 & 145 & 3,9 & 0,43 & 0,59 \\
\hline $18 / 28$ & 55 & 17,9 & 22,1 & 0,68 & II & 600 & 204 & 3,7 & 0,33 & 0,40 \\
\hline \multicolumn{11}{|c|}{ Кропивнянське лісництво } \\
\hline $2 / 4$ & 39 & 17,3 & 20,9 & 0,71 & $\mathrm{I}^{\mathrm{a}}$ & 1010 & 265 & 6,8 & 0,44 & 0,54 \\
\hline $1 / 13$ & 54 & 27,5 & 29,9 & 0,66 & $\mathrm{I}^{\delta}$ & 402 & 285 & 5,3 & 0,51 & 0,56 \\
\hline \multicolumn{11}{|c|}{$\begin{array}{c}\text { На землях із глибоким заляганням кам'янистих порід } \\
\text { Смолівське лісництво }\end{array}$} \\
\hline $67 / 23$ & 37 & 15,8 & 14,1 & 0,99 & I & 2520 & 350 & 9,5 & 0,42 & 0,38 \\
\hline $54 / 17$ & 57 & 25,1 & 25,2 & 0,83 & $\mathrm{I}^{\mathrm{a}}$ & 805 & 375 & 6,6 & 0,37 & 0,44 \\
\hline \multicolumn{11}{|c|}{ Івницьке лісництво } \\
\hline $17 / 2$ & 38 & 18,6 & 19,2 & 0,95 & I & 1185 & 330 & 8,7 & 0,49 & 0,50 \\
\hline $18 / 22$ & 39 & 19,3 & 21,0 & 0,98 & $\mathrm{I}^{\mathrm{a}}$ & 1000 & 320 & 8,2 & 0,49 & 0,54 \\
\hline $13 / 4$ & 57 & 19,0 & 20,1 & 0,75 & I & 990 & 310 & 5,4 & 0,33 & 0,35 \\
\hline $27 / 3$ & 55 & 20,6 & 23,2 & 0,80 & $\mathrm{I}$ & 780 & 330 & 6,0 & 0,37 & 0,42 \\
\hline
\end{tabular}

Інтенсивність росту дерев сосни в цих культурах зумовлена не умовами місцезростання (культури сформувались на грунтах без кам'янистих порід), а проведеною господарською діяльністю. В цих культурах на одному гектарі збереглась найбільша кількість (2520 шт.) дерев, що перевищує більше ніж у два рази кількості дерев сосни, ніж у культурах Кропивнянського й Івницького лісництв і в 1,5 раза, яке зазначено в таблицях ходу росту (Shvidenko, Strochinskii \& Poliakov, 1987).

Мала кількість (476) дерев сосни на гектарі в 37-річних культурах Коростишівського лісництва, низька середня висота $(15,8$ м) і найбільший середній діаметр (22,0 cм) обумовлені наявністю близького залягання кам'яних валів до денної поверхні. Ці грунтові умови уповільнили ріст дерев сосни за висотою, погіршили очищення їх від гілок i, як наслідок, значно зменшили (до $145 \mathrm{~m}^{3}$ на гектарі) запас стовбурової деревини. Але потрібно наголосити, що всі культури сприятливо впливають на навколишнє середовище. На час обстеження культури зберегли повноту 0,71, а зімкнутість крон близько одиниці. Грунт вкритий суцільним шаром підстилки, не виявлено ослаблених, суховерхівкових і сухих дерев. Тому можна сподіватись, що і в старшому віці ці культури будуть виконувати значну екологічну роль.

Найбільших розмірів на цих грунтах дерева сосни (висоти 27,5 м і діаметра 29,9 см) досягли в 54-річних культурах Кропивнянського лісництва. До цих культур за висотою (24,0 м) наближаються 55-річні, які створені в Дубовицькому лісництві (див. табл. 1). До часу обстеження найменший запас стовбурової деревини (204 м ${ }^{3}$ на гектарі) мають 55-річні культури Коростишівського лісництва, найбільший $\left(385\right.$ м $\left.^{3}\right)$ - 56-річні культури Дубовицького лісництва, а в 54-річних культурах Кропивнянського лісництва запас стовбурової деревини становить $285 \mathrm{~m}^{3}$ на гектарі.

У культурах, які створені на землях без кам'янистих порід у грунті, сосна звичайна проявляє ріст за I-I ${ }^{\mathrm{a}}$ бонітетами. До часу обстеження в культурах збереглось 780-990 дерев на гектарі, вони досягли середньої висоти 19,0 і 20,6 м у 57-55-річних культурах Івницького лісництва і найвищої $(25,1$ м) - у Смолівському лісництві. У такій же послідовності за величиною розташований і запас стовбурової деревини. Найвищий $\left(375 \mathrm{~m}^{3}\right)$ він у Смолівському лісництві, менший $\left(330 \mathrm{~m}^{3}\right)$ у 55 річних культурах в Івницькому лісництві та найменші (310 м ${ }^{3}$ на гектарі) теж у 55-річних культурах цього ж лісництва.

У Лугинському лісництві Житомирської обл. запас стовбурової деревини 50-річних культур сосни становить 332-377 м ${ }^{3}$ на гектарі (Gordienko, Ribak \& Gordienko, 1996). Отже, запас стовбурової деревини сосни звичайної в культурах, які створені на землях із наявністю 
кам'янистих порід, може досягти однакової величини 3 культурами, які створені на землях без каміння.

У культурах, які відповідають I ${ }^{\mathrm{a}}$ бонітету і сформувались на грунтах із близьким заляганням кам'янистих порід і без останніх у грунті, дерева сосни проявляють однакову інтенсивність росту за висотою і діаметром.

Загалом культури, які сформувались на грунтах без наявності кам'янистих порід, до часу обстеження зберегли високу $(0,95-0,99)$ повноту, що сприяло очищенню дерев від гілок (крона займає 21,5-29,0 \% за висотою) і забезпечило досить великий запас стовбурової деревини (320-350 м³ на гектарі) (табл. 2). За нашими даними, в культурах сосни звичайної, які сформувались на грунтах із близьким заляганням каміння до денної поверхні, довжина бічних гілок більша, ніж у культурах, що сформувались на грунтах без кам'янистих порід. Так, у 37-річних культурах Дубовицького лісництва довжина бокових гілок крони дерев сосни становить у межах 94-269 см, Кропивнянського лісництва 152-206 см і в культурах Смолівського лісництва довжина бокових гілок становить в межах 45-180 см, Івницького - 49-66 см.

Табл. 2. Характеристика дерев і крони сосни в культурах

\begin{tabular}{|c|c|c|c|c|c|c|c|c|c|c|c|c|c|}
\hline \multirow{3}{*}{$\begin{array}{l}\text { Квар- } \\
\text { тал/ } \\
\text { виділ }\end{array}$} & \multirow{3}{*}{$\begin{array}{l}\text { Вік, } \\
\text { роки }\end{array}$} & \multicolumn{2}{|c|}{ Середні } & \multirow{3}{*}{ Повнота } & \multicolumn{5}{|c|}{ Кількість дерев на 1 га } & \multirow{3}{*}{$\begin{array}{c}\text { Висота } \\
\text { до пер- } \\
\text { шої } \\
\text { живої } \\
\text { гілки, м } \\
\end{array}$} & \multicolumn{2}{|c|}{$\begin{array}{c}\text { Подовженість } \\
\text { крони }\end{array}$} & \multirow{3}{*}{$\begin{array}{l}\text { Діаметр } \\
\text { крони, м }\end{array}$} \\
\hline & & \multirow{2}{*}{$\begin{array}{c}\text { висота, } \\
\text { м }\end{array}$} & \multirow{2}{*}{$\begin{array}{c}\text { діаметр, } \\
\text { см }\end{array}$} & & \multicolumn{2}{|c|}{ ділових } & \multicolumn{2}{|c|}{ дров'яних } & \multirow{2}{*}{$\begin{array}{c}\text { разом, } \\
\text { шт. }\end{array}$} & & \multirow[b]{2}{*}{ M } & \multirow{2}{*}{\begin{tabular}{|c|} 
за \\
висотою \\
дерев \\
\end{tabular}} & \\
\hline & & & & & шт. & $\%$ & шт. & $\%$ & & & & & \\
\hline \multicolumn{14}{|c|}{ На землях із близьким заляганням кам'янистих порід } \\
\hline \multicolumn{14}{|c|}{ Дубовицьке лісництво } \\
\hline $31 / 5$ & 37 & 17,0 & 20,1 & 0,96 & 332 & 28,5 & 833 & 71,5 & 1165 & 13,4 & 3,6 & 21,2 & 2,5 \\
\hline $16 / 17$ & 56 & 24,1 & 21,9 & 0,79 & 543 & 56,9 & 412 & 43,2 & 955 & 18,6 & 5,5 & 22,8 & 2,3 \\
\hline \multicolumn{14}{|c|}{ Коростишівське лісництво } \\
\hline $18 / 26$ & 37 & 15,8 & 22,0 & 0,71 & 72 & 15,1 & 404 & 84,9 & 476 & 11,0 & 4,8 & 30,3 & 2,5 \\
\hline $18 / 28$ & 55 & 17,9 & 22,1 & 0,68 & 148 & 24,7 & 452 & 75,3 & 600 & 8,0 & 8,1 & 45,1 & 2,8 \\
\hline \multicolumn{14}{|c|}{ Кропивнянське лісництво } \\
\hline $2 / 4$ & 39 & 17,3 & 20,0 & 0,71 & 660 & 65,4 & 350 & 340 & 1010 & 13,1 & 4,2 & 24,3 & 1,8 \\
\hline $1 / 13$ & 54 & 27,5 & 29,9 & 0,66 & 398 & 99,0 & 4 & 1,0 & 402 & 18,6 & 8,1 & 22,3 & 4,0 \\
\hline \multicolumn{14}{|c|}{ На землях із глибоким заляганням кам'янистих порід } \\
\hline \multicolumn{14}{|c|}{ Смолівське лісництво } \\
\hline $67 / 23$ & 37 & 15,8 & 14,1 & 0,99 & 650 & 25,8 & 1870 & 74,2 & 2520 & 12,4 & 3,4 & 21,5 & 1,8 \\
\hline $54 / 17$ & 57 & 25,1 & 24,8 & 0,83 & 508 & 63,1 & 297 & 36,9 & 805 & 20,8 & 4,3 & 17,1 & 2,9 \\
\hline \multicolumn{14}{|c|}{ Івницьке лісництво } \\
\hline $17 / 2$ & 38 & 18,6 & 19,2 & 0,95 & 579 & 48,9 & 605 & 51,1 & 1185 & 14,2 & 4,4 & 23,5 & 2,5 \\
\hline $18 / 22$ & 39 & 19,3 & 21,0 & 0,98 & 591 & 59,1 & 409 & 40,9 & 1000 & 13,7 & 5,6 & 29,0 & 2,0 \\
\hline $13 / 4$ & 57 & 19,0 & 20,2 & 0,75 & 698 & 70,5 & 292 & 29,5 & 990 & 16,1 & 2,9 & 15,3 & 2,9 \\
\hline $27 / 3$ & 55 & 20,6 & 23,0 & 0,80 & 721 & 92,4 & 59 & 7,6 & 780 & 17,1 & 3,5 & 17,0 & 3,8 \\
\hline
\end{tabular}

Отже, збільшення приросту бокових гілок дерев сосни звичайної зменшило, причому значно, запас стовбурової деревини в усіх культурах, які сформувались на грунтах iз близьким заляганням каміння до денної поверхні.

За нашими даними, у дерев сосни культур, які створені на грунтах із близьким заляганням каміння до цієї поверхні, найдовші гілки розташовані на висоті 14,5 м (Дубовицьке лісництво) і на висоті 14,4 м (Смолівське лісництво), у культурах, які сформувались на грунтах без кам'янистих порід, перші від землі гілки мали найбільшу довжину (див. табл. 2). Ці гілки в Смолівському лісництві розташовані на висоті 12,9 м, а в Івницькому лісництві - на висоті 14,8 м.

Інтенсивність росту за висотою до 30-31 років дерев сосни звичайної в культурах на землях без кам'янистих порід дещо вища (в цей період різниця становить понад один метр), ніж у культурах із наявністю останніх у грунті. Після цього віку інтенсивність росту дерев сосни на обох ділянках однакова, але висота дерев сосни дещо більша в культурах без каміння в грунті. Середній діаметр дерев сосни вищий в культурах без каміння в грунті впродовж спостережень.

Проте, незважаючи на досить високий запас стовбурової деревини в культурах, які створені на землях із наявністю каміння, товарна структура дерев сосни в них низька. У 56-річних насадженнях Дубовицького і 55-річних Коростишівського лісництв до часу обстеження ділових дерев збереглось 24,7-56,9 \% і тільки у 54-річних культурах Кропивнянського лісництва збе- реглось 99,0 \% ділових дерев сосни звичайної. У культурах, які створені на цих землях, очищення стовбурів сосни від гілок слабке. Перша гілка від землі бере початок із висоти 5,5-8,1 м, а крона за висотою дерев займає $22,3-45,3 \%$.

У культурах, які створені на землях без наявності каміння в грунті, частка ділових дерев становить 63,1 70,5 \%. Перші гілки від землі збереглися на висоті 16,120,8 м, зате очищення стовбурів від гілок краще крона займає за висотою дерева 15,3-17,1 \%. У цих середньовікових культурах, за малим винятком, загальна довжина гілок однакова в культурах, які створені на землях із наявністю каміння в грунті та без них.

Висновки. Проведення інтенсивних доглядових рубань у жердинному віці, а відповідно зниження повноти насаджень зумовлює слабке очищення стовбурів від гілок, супроводжується зниженням товарної структури деревостану й обумовлює наявність малої кількості ділових сортиментів дерев сосни звичайної. У середньовікових культурах на землях із наявністю кам'янистих порід інтенсивність росту дерев сосни і запас стовбурової деревини залежить від кількості та характеру розташування каміння. За умов відсутності суцільного шару щебеню і окремо розташованих валунів, коріння проникають у глибокі горизонти грунту. Це забезпечує збереження досить великої кількості дерев сосни звичайної, інтенсивний їх ріст і високий запас стовбурової деревини на одиниці площі. 


\section{Перелік використаних джерел}

Gordienko, M. I., \& Gordienko, N. M. (2005). Lisivnichi vlastivosti derevnih roslin. [Branch properties of wood plants]. Kyiv: Vistna. 818 p. [In Ukrainian].

Gordienko, M. I., Mayrer, V. M., \& Kovalevskiy, S. B. (2000). Metodichni vkazivki do vivchenij ta doslidgenij lisovih kyltyr. [Methodological guidelines for the study and research of forest crops]. Kyiv. 103 p. [In Ukrainian].

Gordienko, M. I., Ribak, V. O., \& Gordienko, N. M. (1996). Lisovi kulturi sosni zvichainoi na Pivdni Kievskogo Polisia. [Forest crops of pine forest common in the South of Kiev Polissya]. Kyiv: NAU. 192 p. [In Ukrainian].

Mironov, V. V. (1977). Ekologia hvoinih porod pri iskustvennov lesovozobnovlenii. [Ecology of coniferous species under artificial resumption]. Moscow: Lecnaia promyshlennoct. 232 p. [In Russian].

Pogrebniak, P. S. (1968). Obschee lesovodstvo. [General forestry]. Moscow: Kolos. 440 p. [In Russian].

Shvidenko, A. Z., Strochinskii, A. A., \& Poliakov, V. K. (1987). Normativno-spravochnii material dla taksacii lesov Ukraini i Moldavii. [Normative reference material for forest inventory of Ukraine and Moldova]. Kyiv: Urozay. 560 p. [In Ukrainian].

С. Б. Ковалевский, А. В. Кроль

Национальный университет биоресурсов и природопользования Украины, г. Киев, Украина

\section{ОСОБЕННОСТИ РОСТА 30-50-ЛЕТНИХ КУЛЬТУР СОСНЫ ОБЫКНОВЕННОЙ ЖИТОМИРСКОГО ПОЛЕСЬЯ НА ПОЧВАХ С КАМЕНИСТЫМИ ПОРОДАМИ}

Выявлены закономерности роста и развития древесных растений в насаждениях жерднякового возраста и средневозрастных культурах сосны обыкновенной Житомирского Полесья. Исследования проведены на участках с различной глубиной залегания каменистых пород в почве. Установлено, что на производительность насаждений в данном возрастном периоде влияют не только грунтовые условия, а и проведение рубок ухода различной интенсивности, что, в свою очередь, сказывается на задернении почвы, конкуренции за влагу и элементы минерального питания между древесными и травяными видами. Оценено влияние наличия в почве каменистых пород, в частности их залегания на разной глубине и количестве, на формирование, развитие и разрастание корневых систем, что в дальнейшем определяет рост и устойчивость насаждений в целом. Установлено, что интенсивность роста по высоте до 30-31 года деревьев сосны обыкновенной в культурах на землях без каменных пород несколько выше (в этот период разница составляет более одного метра), чем в культурах с наличием последних в почве. После этого возраста интенсивность роста деревьев сосны на обоих участках одинакова, но высота деревьев сосны несколько больше в культурах без камней в почве. Средний диаметр деревьев сосны выше в культурах без камней в почве в течение всего времени наблюдений. Однако, несмотря на достаточно высокий запас стволовой древесины в культурах, созданных на землях с наличием камней, товарная структура деревьев сосны в них низкая.

Ключевые слова: сосновые культуры, кристаллические породы, почва.

S. B. Kovalevskii, A. V. Krol

National University of Life and Environmental Sciences of Ukraine, Kyiv, Ukraine

\section{SOME PECULIARITIES OF GROWTH OF 30-50-YEAR-OLD CULTURES OF SIVER PINE ON STONY SOILS IN ZHYTOMYR POLISSYA}

A forest is a complex plant group that varies in space and time throughout its period of existence for each of the stages of its inherent features of growth, development, interaction and mutual influence of all its components. The plantation in the peculiar age is characterized by intense absorption of nutrients and moisture from the soil, the formation of a large amount of litter by the end of the 30 -year-old age, the absence or weak development of herbaceous plants, the strong differentiation of trees in size. From the end of the third decade, the crown of trees begins to crumble in the plantations of the polar age. In this period of closed plantings there is an intensive growth of tree species in height. In medieval cultures, the formation of trunks and crowns of all wood species is prolonged, but the liquefaction of the latter, the illumination and warming of the soil, which promotes the settlement of herbaceous and tree plants, intensifies. Significant influence on the intensity of growth and development of tree species is caused by the root system of the tree, the formation of which occurs depending on the type of plants and soil conditions. A small number of pine trees per hectare, their low average height are due to the presence of a close occurrence of stone shafts. These soil conditions slowed the growth of pine trees in height, worsened the cleaning of the branches and, consequently, significantly reduced the supply of stem wood. In the crops of ordinary pine, which are formed on soils with a close occurrence of stones to the daytime surface, the length of the lateral branches is greater than in cultures formed on soils without rocky rocks. The intensity of growth in height up to 30 years of pine trees of cultures on land without rocks is a bit more than of cultures with the presence of the latter in the soil. After this age, the intensity of the growth of pine trees on both sites is the same, but the height of pine trees is slightly larger of cultures without stones in the soil. The average diameter of pine trees is higher of cultures without stones in the soil throughout the time of observation. Despite a rather high stock of stem wood in crops grown on areas with the presence of stones, the commodity structure of pine trees there is low. In medieval cultures on lands with the presence of rocks, the intensity of the growth of pine trees and the supply of stem wood depends on the number and nature of the location of stones. In the absence of a continuous layer of gravel and separate boulders, roots penetrate into the deep horizons of the soil. This ensures the preservation of a fairly large number of pine trees of ordinary, intensive growth and a high stock of stem wood per unit area.

Keywords: pine cultures; crystalline rocks; soil. 